\title{
PALM OIL POLITICS IN MALAYSIA AND INDONESIA: COMPETITION OR COLLABORATION?
}

\author{
Hangga Fathana \\ Department of International Relations \\ Faculty of Psychology and Socio-Cultural Sciences \\ Universitas Islam Indonesia \\ Yogyakarta, Indonesia \\ (hangga.fathana@uii.ac.id) \\ DOI: https://doi.org/10.22452/jati.vol23no2.3
}

\begin{abstract}
Threats to food security have increased around the world following the increasing threat of climate change over the last few years. Such threats have also become apparent in Southeast Asia. This region is home to $10 \%$ of the world's population and is host to the world's largest rice and palm oil exporters. Malaysia and Indonesia play an important role in securing the future supplies of palm oil because these two countries account for $85 \%$ of global palm oil production. However, the impact of climate change may cause a food crisis in the future, thus raising the possibility of food losses in the region. This paper is an attempt to revisit the position of Malaysia and Indonesia in Southeast Asia with a particular emphasis on the two countries' role in countering future food crises. It is argued that the current economic relation policies of Malaysia and Indonesia have somewhat neglected the importance of future food security in Southeast Asia. The idea of establishing a council for palm oil producers between the two countries is seen as a 'game changer'. However, the effect of such an effort is uncertain, and it pays little attention to the need for securing Southeast Asia's future food system. The council needs to commit to moving beyond a 'revenue driven' rationale. Concerning a regional engagement approach, stronger economic relations between Malaysia and Indonesia can be attributable to a more resilient food system in Southeast Asia.
\end{abstract}

Keywords: Malaysia, Indonesia, palm oil, bilateralism $\mathcal{E}$ Southeast Asia 


\section{Introduction}

Food production plays an important role in Southeast Asia's regional stability. In addition to recent issues in the ASEAN economic community, many believe that it is hard to foresee the scope of the potential crisis of food security in Southeast Asia. Over the last few years, the region has encountered an increasing number of food losses as a result of climate change (Tian \& Lassa, 2015). For example, floods and typhoons have become more common, and these natural disasters had damaged crops and impacted food production in Indonesia, the Philippines, Thailand and Vietnam. The region has a land area of 4.5 million $\mathrm{km}^{2}$, with the majority used as cropland and forest, thus making its economies highly reliant on agriculture and natural resources (Capistrano \& Marten, 1986).

Considering that the region is home to the world's biggest rice exporters, Southeast Asia also plays a pivotal role in supplying palm oils (McMahon, 2013). More specifically, Malaysia and Indonesia produce $85 \%$ of the world's palm oil (Nersesian, 2015). Therefore, the two countries share common interests because they are at similar levels of agricultural development and dominate the palm oil supply chain. Both countries also share future common challenges because palm oil production faces criticisms in terms of sustainability and environmental impacts in the midst of rising market demand. This paper attempts to clarify how the Malaysian and Indonesian governments can address the issue of future food security, with a particular emphasis on the two countries' response to the rising demand for sustainable palm oil production.

The paper is organised as follows: The first section discusses the role of palm oil as a major food commodity and examines the features of palm oil production in Malaysia and Indonesia. From the perspective of neomercantilism, the second section analyses the effects of the creation of the Council of Palm Oil Producing Countries (CPOPC) as an attempt to respond to pressure from developed countries, international NGOs and global corporations. These findings support the conclusion that Malaysia and Indonesia, along with other stakeholders, need to revisit palm oil production beyond a 'revenue driven' rationale. Higher policy priorities on environmental and social safeguarding are needed to reduce the excesses of palm oil production. These are not an easy alternative, but the options may be worse. 


\section{Research Approach and Methodology}

In setting up the research paradigm, this paper acquires interpretivism. It believes that knowledge and reality are socially constructed than objectively explained (Creswell, 2009; Thanh \& Thanh, 2015; Willis, Jost, \& Nilakanta, 2007). This paper also adopts the qualitative approach in data collection, as it provides more direct and comprehensive interpretation related to the subject matter (Bernhard, 2007).

To account for the research objectives, this paper employs descriptive inference. Inference itself is described as "the process of using the facts we know to learn the fact that we do not know" (King, Keohane, \& Verba, 1994). Barakso, Sabet, and Schaffner (2013) define the descriptive inference as "the act of describing some aspect of the world". Through this approach, this paper seeks to provide a descriptive analysis of the political aspect of IndonesianMalaysian relations in palm oil industries. It would sketch the current situation of the two countries relations from the cooperative and competitive motives.

Accordingly, this paper conducts an extensive literature review from various sources on palm oil politics to enhance the observation of the current discourse. This paper mainly utilises secondary data from trusted sources such as the Food and Agriculture Organization of the United Nations, the Malaysian Palm Oil Board, and the United States Department of Agriculture.

\section{Palm Oil in Southeast Asia: Current Discourse}

The views on sustainability have a much-shaped discussion on palm oil in Southeast Asia. Ivancic and Koh (2016) emphasised the need to strengthen the proactive role of the governments in responding to the activities led by interests groups and pressure groups. The governments should hand in hand with those groups to take greater leverage of the issue. They also highlighted the need to enhance investment on technology to accelerate progress on sustainable palm oil (Ivancic \& Koh, 2016).

From a different point of view, Nesadurai analysed the role of private regulation to support palm oil sustainability. Among scepticism of current developments, it is argued that social processes may contribute to creating significant changes in private regulatory order. These include surveillance, normalising judgement and knowledge transfer (Nesadurai, 2018a). She also further argued that this private regulatory somehow led to private 
developmental interventions, as seen in Indonesia and Malaysia (Nesadurai, 2018b).

Literatures of palm oil politics in Southeast Asia also include issues on ways to improve production capacity. Land grabs are proven as part of the instruments to boost up the crop (Hall, 2011). Hall also believed that such land control is also significant to improve the production capacity not only to palm oil, but also some other prominent agricultural products in Southeast Asia such as coffee, cocoa, and rubber. Hall further analysed the role domestic states and multinational corporations in handling the flows of transnational capital across the countries. He argued that land grabs in Southeast Asia is more as political policy and not a purely professional approach to improve agricultural products.

Furthermore, the literature review also alludes to the relations between Indonesia-Malaysia in a broader context. Dollah and Mohamad (2007) highlighted the relations of the two countries has changed over time. The positive relationship between Indonesia and Malaysia has had received little attention. More literature is needed to analyse the benefits of the two countries relations. Dollah and Mohamad (2007) argued that trade between MalaysiaIndonesia could catalyse stronger economic relations between the two countries. Positive trade trends between Sabah and Nunukan, Tarakan, and other places in Indonesia should be seen as opportunities to embrace (Dollah \& Mohamad, 2007).

The economic relations of Indonesia and Malaysia is also seen from the historical perspective, particularly on the Strait of Malacca that has benefited the two countries throughout much of the history (Mhd. Nur M. S., 2018). Trades through the strait have shaped the foreign economic relations and developed social, political, and cultural activities in the surrounding area. Moreover, to create stronger relations, the two countries should develop confidence building and nurture through a rational approach (Wardhani, 2009).

\section{Stirring the Market: Competition and Collaboration}

Palm oil production plays a pivotal role in the economies of Malaysia and Indonesia. Palm oil accounted for $8.9 \%$ of Indonesia's total exports in 2014, thus making it the third largest exported commodity in Indonesia after coal and petroleum. In Malaysia, palm oil accounted for $4.5 \%$ of total exports in 2014 (Simoes \& Hidalgo, 2014). Malaysia was predominantly the largest exporter up to 1997, with Indonesia's exports increasing since that year and 
eventually passing Malaysia in terms of areas planted with oil palm (see Table 1).

In terms of food supply, palm oil is the world's most-consumed oil, with as many as 3 billion consumers in 150 countries. It accounts for $55.9 \%$ of the total vegetable oils consumed in the world and is used in a wide range of food products, such as cooking oil, shortenings and margarine (Sime Darby Plantation, 2014). The major consumers of palm oil are China, India, Indonesia and European Union countries. A strong causal relationship exists between palm oil production and food security because it influences the trend of the Food and Agriculture Organization of the United Nations (FAO) Price Index, which measures the monthly changes in the international prices of a basket of food commodities. The FAO Price Index consists of the average of five commodity group price indices: meat, dairy, cereals, vegetable oils and sugar. For instance, in April 2016, the FAO Price Index increased for the third consecutive month after experiencing significant decreases since 2013. This increase was led by the $4.1 \%$ increase in the FAO Vegetable Oil Price Index owing to the less than promising palm oil production outlook exacerbated by growing worldwide demand (FAO, 2016).

The future demand for palm oil is expected to double by 2020 with a $9.5 \%$ annual increase, thus amounting to demand of as much as 2.5 million extra tonnes of palm oil. This palm oil boom has enabled Malaysia and Indonesia to enjoy the benefits of increased commodity exports. The two countries have increased their production capacity by 2.29 million tonnes per annum to meet the world's growing demand for palm oil (United States Department of Agriculture, 2010).

Table 1: Features of the Palm Oil Industry in Malaysia and Indonesia (2014)

\begin{tabular}{|l|l|l|}
\hline Features & Malaysia & Indonesia \\
\hline Area planted with oil palm & $>5$ million ha & $>10$ million ha \\
\hline $\begin{array}{l}\text { Export contribution (\% of the } \\
\text { total export) }\end{array}$ & $4.5 \%$ & $8.9 \%$ \\
\hline $\begin{array}{l}\text { The average annual increase in } \\
\text { production }\end{array}$ & 0.82 million tonnes & $\begin{array}{l}1.47 \text { million } \\
\text { tonnes }\end{array}$ \\
\hline $\begin{array}{l}\text { Production (000 t crude palm } \\
\text { oil (CPO)) }\end{array}$ & 18,785 & 26,900 \\
\hline Percentage of CPO exported & $90.6 \%$ & $70 \%$ \\
\hline
\end{tabular}

Source: Cramb and McCarthy (2016).

As a result of this palm oil boom, Malaysia and Indonesia have both competed and collaborated to ensure that the growing demand will benefit 
each of them. Under such conditions, some questions arise regarding how Malaysia and Indonesia have organised their key actors and relationships in the face of this opportunity, what type of game shapes the competition between the two countries and what types of collaboration both countries have engaged in to harness the opportunities generated by the boom.

In terms of competition, Malaysia and Indonesia both rank palm oil production as a policy priority at the national level. First, the two countries are taking steps to ensure that their oil palm outputs have good quality and comply with the sustainability principles required by buyers. In doing so, the Malaysian government through the Malaysian Palm Oil Board (MPOB) sets policies to boost the position of Malaysian palm oil in the global value chain. These policies cover domestic capacity building, including adopting a strong market- and industry-oriented research and development programmes, undertaking the transfer of technologies and commercialising research results. The policies of MPOB also cover external partnerships in terms of forging active partnerships in technology development and utilisation with private and public sectors, strengthening international linkages and research collaboration and promoting global awareness, appreciation and demand for Malaysian oil palm and products (Malaysian Palm Oil Board, 2015).

Malaysia appointed a special board to secure palm oil production, whereas Indonesia previously included palm oil as part of the country's Masterplan of Acceleration and Expansion of Indonesia Economic Development (MP3EI) 2011-2025. The Indonesian government believed that developing both upstream and downstream capabilities would enable the country to produce high-quality output at a competitive price. MP3EI outlined three pillars to escalate the value of Indonesian palm oil: (1) improving regulations and policies; (2) increasing connectivity through infrastructure improvement; and (3) developing human resources and science and technology (Coordinating Ministry for Economic Affairs, 2011).

However, this approach was deliberately terminated after the 2014 general election, with President Joko Widodo indicating that his administration was not in favour of continuing MP3EI ("Jokowi Isyaratkan Tak Lanjutkan Program MP3EI dalam Pemerintahannya", 2014). He later introduced the Crude Palm Oil Supporting Fund (CSF), which aims to (1) strengthen the palm oil production of smallholders; (2) improve human resources, research and development; and (3) monitor palm oil production (Sari, 2015). This strategy sparked criticism because it might lead to a decrease in national revenue and undermine the purchasing power of smallholders. 
Second, in regard to the creation of the Indonesian CSF, competition between the two countries can also be seen in their tariff policies. In 2014, the palm oil price decreased to below USD750 per metric tonne. In response, the Malaysian government eliminated its export tariff for CPO. The policy was expected to boost CPO sales in the midst of price decreases over the previous five consecutive years. The Indonesian government pursued a similar policy to counter the competitive price of Malaysian CPO. As a result, the two countries became embroiled in a sort of 'tax war', which forced them to contend with a competitive CPO price in the global market (Taylor, 2014). This 'tax war' between the two biggest palm oil producers indicates that Malaysia and Indonesia share common goals, namely, an aspiration to be the key player in the global palm oil market.

This zero-tariff policy had a somewhat positive response, with the price of CPO increasing steadily in both countries since the end of 2014. Recently, the Indonesian government re-imposed its CPO tax to secure its national savings. The government also plans to implement a moratorium on new oil palm plantation concessions via Presidential Instruction No. 8/2015. This policy was designed in the face of foreign criticisms over the unsustainable practices used in Indonesian palm oil production, which cause environmental damage to planted areas (Amindoni, 2016). These policies of the Indonesian government, particularly the tax hike, may benefit Malaysian palm oil by making it more attractive and competitive in the global market (Tuah, 2016).

The implementation of Malaysia and Indonesia of competitive tax policies to improve CPO sales can be perceived as pragmatic; however, it produces unsustainable competition. This practice creates adverse effects on the global palm oil market and risks the economic relations between Malaysia and Indonesia. Such a 'race to the bottom' can be destructive and can lead to a no-win situation for both countries if they persist in extending this approach (Wong, 2016).

Third, the competition between Malaysia and Indonesia can also be seen from their response towards the growing demand for sustainable palm oil. Both countries are establishing their standard for sustainable palm oil production. In 2011, the Indonesian government created The Indonesian Sustainable Palm Oil (ISPO) standard to help local oil palm growers conform to higher agricultural standards (Artharini, 2016). To increase the competitiveness of Indonesian palm oil, the adoption of ISPO is compulsory for all Indonesian palm oil growers. The Malaysian government soon followed Indonesia's ISPO initiative by creating the Malaysian Sustainable Palm Oil 
(MSPO) standard in 2013. Unlike Indonesia, Malaysia made MSPO voluntary, arguing that MSPO certification is dedicated to facilitating Malaysian smallholders in scaling up their business with sustainable practices (Experts in Sustainable Forest \& Agricultural Advice, 2015).

Despite these competitive and progressive policies for boosting revenue from palm oil, it should be noted that the two countries also engage in collaboration. Malaysia and Indonesia share a political and business culture that facilitates the integration of business and policy elites (Varkkey, 2012). In such a context, Cramb and McCarthy (2016) proposed the term 'regionalisation of the palm oil industry' to describe the partnership between the two countries. This term emerged from the perspective that the interaction between economic and political power within the palm oil industrial complex has enabled key actors to undertake palm oil expansion across the entire region (Pye, 2009).

Accordingly, the regionalisation of the palm oil industry has allowed the governments of Malaysia and Indonesia, as well as the corporations and societies in both countries, to interact across the border. Corporate actors from each country have extended their business reach, thus allowing Indonesian companies to undertake technology upgrading and attract capital inflows from Malaysian companies. This scheme is beneficial for Indonesian companies and allows Malaysian companies to access Indonesian labour and expand production by using Indonesian land (Cramb \& McCarthy, 2016).

At the government level, collaboration has also extended to capacity building in downstream industries. Malaysia and Indonesia have agreed to explore the best practices of palm oil supply management to make their palm oil industries more resilient during commodity price decreases. The two countries also work hand in hand to improve public's perception of palm oil and strengthen practices for producing sustainable palm oil. Such important agreements are also fostered by Malaysia's and Indonesia's commitment to encourage greater capital inflows and to promote a cross-border palm oil industry ("Indonesia dan Malaysia Kerjasama Industri Hilir Sawit", 2015). Moreover, the two countries have also agreed to establish an exclusive economic zone in Indonesia for joint palm oil production to help the downstream industry ("Indonesia, Malaysia Team Up for Palm Oil Industrial Zone", 2015). Accordingly, Indonesia proposed several areas such as Pontianak, West Kalimantan; Dumai, Riau; or East Kalimantan to house manufacturers that will process $\mathrm{CPO}$.

With regard to ISPO and MSPO, Malaysia and Indonesia are also committed to closing the gap between the two certification schemes. The 
synergy between the two schemes is pivotal in boosting the sustainability of the region's palm oil industry. However, dissimilarities in regulations between the two countries have somewhat hindered this process, thus making it impossible for them to share common practices to bridge the gap. For instance, the Malaysian Official Secrets Act 1972 prohibits Malaysia explicitly from providing a palm oil concessions map (Jacobson, 2016).

\section{Reaching Beyond 'Revenue Driven' Industry?}

ISPO and MSPO are often perceived as a response to the growing demand for sustainable palm oil. Moreover, these schemes are also reactions by Malaysia and Indonesia to adhere to the palm oil sustainability principles regulated under the Roundtable on Sustainable Palm Oil (RSPO), Which was constructed as a 'stakeholder initiative', particularly private actors (end-users, producers and NGOs) who share universal environmental principles in palm oil production (Pye, 2016). This voluntary scheme was proposed in 2002 and has since become the primary global framework for measuring the sustainability of palm oil production. As a result, palm oils with RSPO certificates are more competitive than uncertified oils. However, because this scheme is not obligatory, only $20 \%$ of palm oils worldwide are RSPO certified, and compliance with RSPO must be backed by national laws and related regulations (Experts in Sustainable Forest \& Agricultural Advice, 2015).

The RSPO initiative was developed in response to European campaigns on palm oil production as the one responsible for the destruction of the Indonesian rainforest and forests fires in 1997. RSPO is implemented under specific principles and criteria ( $\mathrm{P} \& \mathrm{C})$, which are determined by 'equal and fair' discussions among its members. In 2015, RSPO membership consisted of 15 banks and investors, 143 oil palm growers, 131 processors and traders, 564 consumer goods manufacturers, 61 retailers and 40 NGOs (RSPO, 2015). Considering that they constitute the majority of RSPO members, consumer goods manufacturers perceive the importance of sustainable palm oil production as an extension of the 'triple bottom line' theory proposed by Elkington (1998), who argued that 'the environmental bottom line' and 'the social bottom line' do not oppose 'the economic bottom line' but are in fact needed to secure a corporation's future profits (Elkington, 1998). Corporations with a higher awareness of social and environmental issues will be more competitive and retain more profitable sales. 
Table 2: Comparisons between RSPO, MSPO and ISPO

\begin{tabular}{|c|c|c|c|}
\hline Standard & RSPO & MSPO & ISPO \\
\hline Initiators & Stakeholders & Government & Government \\
\hline Year of Conception & 2002 & 2013 & 2011 \\
\hline Environment & $\begin{array}{l}\text { Details, clearly } \\
\text { worded }\end{array}$ & $\begin{array}{l}\text { Undetailed and } \\
\text { rely on national } \\
\text { legislation }\end{array}$ & $\begin{array}{l}\text { Undetailed and } \\
\text { rely on national } \\
\text { legislation }\end{array}$ \\
\hline $\begin{array}{l}\text { High Conservation } \\
\text { Value (HCV) }\end{array}$ & $\begin{array}{l}\text { HCV areas should } \\
\text { be maintained or } \\
\text { enhanced. }\end{array}$ & $\begin{array}{l}\text { Does not } \\
\text { mention } \mathrm{HCV} \\
\text { protection }\end{array}$ & $\begin{array}{l}\text { HCV areas } \\
\text { cannot be } \\
\text { cleared. }\end{array}$ \\
\hline Peatlands & $\begin{array}{l}\text { Voluntarily avoid } \\
\text { peatlands, no } \\
\text { prohibition to } \\
\text { planting on peat }\end{array}$ & $\begin{array}{l}\text { Allows planting } \\
\text { on peatland but } \\
\text { only under } \\
\text { specified } \\
\text { conditions }\end{array}$ & $\begin{array}{l}\text { Allows planting } \\
\text { on peatland } \\
\text { abiding the } \\
\text { guidelines }\end{array}$ \\
\hline $\begin{array}{l}\text { New Planting Cutoff } \\
\text { Dates }\end{array}$ & $\begin{array}{l}\text { November 2007, } \\
\text { new plantings } \\
\text { should not clear } \\
\text { HCV }\end{array}$ & Not specified & Not specified \\
\hline Social & $\begin{array}{l}\text { Most } \\
\text { comprehensive } \\
\text { Social Impact } \\
\text { Assessment (SIA) }\end{array}$ & $\begin{array}{l}\text { Requires SIA, } \\
\text { undetailed }\end{array}$ & $\begin{array}{l}\text { Replacing } \\
\text { AMDAL for SIA }\end{array}$ \\
\hline $\begin{array}{l}\text { Free, Prior and } \\
\text { Informed Consent } \\
\text { (FPIC) }\end{array}$ & $\begin{array}{l}\text { Detailed } \\
\text { guidelines related } \\
\text { to FPIC }\end{array}$ & $\begin{array}{l}\text { FPIC shall be } \\
\text { recorded. }\end{array}$ & $\begin{array}{l}\text { No explicit } \\
\text { reference to } \\
\text { FPIC, focusing } \\
\text { on conflict } \\
\text { settlement }\end{array}$ \\
\hline Worker's Rights & $\begin{array}{l}\text { Detailed guidance } \\
\text { on health and } \\
\text { safety, prohibits } \\
\text { forced labour }\end{array}$ & $\begin{array}{l}\text { Requires } \\
\text { compliance with } \\
\text { the national } \\
\text { policy on } \\
\text { workers' rights }\end{array}$ & $\begin{array}{l}\text { Not specified, } \\
\text { should refer to } \\
\text { government } \\
\text { social security } \\
\text { programme }\end{array}$ \\
\hline Compliance & $\begin{array}{l}\text { Third party } \\
\text { (accredited } \\
\text { auditors), full } \\
\text { compliance } \\
\text { required }\end{array}$ & $\begin{array}{l}\text { Third party } \\
\text { (accredited } \\
\text { auditors) }\end{array}$ & $\begin{array}{l}\text { Third party } \\
\text { (accredited } \\
\text { auditors), full } \\
\text { compliance } \\
\text { required }\end{array}$ \\
\hline Obligatory & Voluntary & Voluntary & Obligatory \\
\hline
\end{tabular}

Source: Experts in Sustainable Forest \& Agricultural Advice (2015). 
Malaysia and Indonesia have further recognised RSPO not only as a tool to remain competitive in the global market but also as a method of capacity upgrading to more environmentally and social, friendly palm oil output. A comparison of RSPO with government-initiative schemes shows that RSPO offers the most comprehensive and objective requirements for sustainable palm oil (see Table 2). In contrast to RSPO, which measures the social risk induced by palm oil by using a detailed SIA, ISPO relies on AMDAL, and MSPO requires only a general measure on SIA (Experts in Sustainable Forest \& Agricultural Advice, 2015). Neither MSPO nor ISPO specify detailed guidance on workers' rights, whereas RSPO has more detailed regulations covering forced, child and women labourers, as mentioned in its $\mathrm{P} \& \mathrm{C}$. Therefore, MSPO and ISPO intentionally set less-absolute P\&C to bridge the gap between palm oil growers who are not yet aware of sustainability issues and growing market demand.

Despite the success story of RSPO, this scheme faces criticisms. However, the existing assumption that RSPO offers a more comprehensive approach than state-driven schemes is not always true (Hapsari, 2016). First, in addition to its comprehensive $\mathrm{P} \& \mathrm{C}, \mathrm{RSPO}$ is alleged to be mere greenwashing, i.e., a deliberate attempt (by corporations) to communicate positive environmental information not matched by improved environmental impacts (Bowen, 2014). RSPO is also accused of delivering a dishonest audit while concealing facts that indicate RSPO corporate members are practising unsustainable palm oil production (Raynolds \& Bennett, 2015). This allegation is somewhat confirmed by a statement from the Secretary-General of RSPO, who stated that the scheme has no right to impose sanctions and penalties on those who breach the RSPO P\&C (Cronin, 2013). This position has revealed RSPO to be vulnerable in terms of the enforcement mechanism, thus causing the public to grow more distrustful of the scheme.

Second, the lack of P\&C enforcement also tests RSPO in terms of one of the 'triple bottom line' principles. RSPO has made it clear that certification will only be issued when oil palm growers are not clearing HCV areas (see Table 2). However, research by NGOs has proven that RSPO companies often ignore this requirement. The first company to be certified, United Plantation, was also found to be involved in HCV clearing in West Kalimantan (Pye, 2016). Other issues have also arisen, such as RSPO companies testing positive for greenhouse gases (GHGs) induced by the palm oil mill effluent (POME). Research has found that uncontrolled amounts of GHGs are potentially being released from POME. In light of these facts, it is reasonable to perceive that the 'environmental bottom line' of RSPO should be treated with caution. 
Third, RSPO has also been tested in terms of its 'social bottom line', with RSPO companies seeing workers' rights as nonbinding principles. RSPO has refused to take any action on labour disputes, believing that it should not serve as a 'judge' or 'police' when conflicts arise. The RSPO companies accused in labour conflicts, such as Musim Mas, have asserted that RSPO has no authority to take part in resolving these conflicts (Pye, 2016). Other social problems also include the case of RSPO companies ignoring customary land rights, breaching laws and court rulings and reacting provocatively (Vidal, 2013). In such situations, the high P\&C standards of RSPO are not upheld by the expected actions of its companies and are merely seen as a toothless tiger.

In the face of these contentious practices of RSPO, Malaysia and Indonesia have recently agreed to strengthen their collaboration by establishing a joint CPOPC ("ASEAN Summit: KL, Jakarta form Council of Palm Oil Producing Countries", 2015). The Council was set up via a charter signed by the two countries and aims to improve the welfare of smallholders. It also deals with the two countries' intentions to practice an environmental friendly palm oil industry by working hand in hand to counter negative campaigns towards unsustainable palm oil. The CPOPC would later extend its membership to Brazil, Thailand, Colombia and other palm oil producing countries. This Council is expected to be the 'palm oil version' of OPEC, which could play a pivotal role in determining the price of CPO (Primadhyta, 2015).

However, given the circumstances of its creation, CPOPC is seen as merely a reaction from the two states to secure their economic interests. Many argue that СРOPC has put more weight on economic concerns than environmental concerns (Rownan, 2015). Malaysia and Indonesia are collaborating to secure the palm oil industry and generate more revenue but are also accused of failing to deliver a quick and comprehensive sustainable practice of palm oil to secure the environment.

Defenders of neomercantilist thinking may find the creation of RSPO, $\mathrm{ISPO}, \mathrm{MSPO}$ and CPOPC quite unsurprising. In particular, the latter is more predictable because states are striving to secure their interests by maintaining export performance. Most of the produced palm oils are export products, with the rest consumed domestically (see Table 1). Despite the decrease in the price of $\mathrm{CPO}$ over the last few years, palm oil exports are expected to increase, and the two countries are reliant to a certain extent on this industry for their trade performance.

Overall, it can be stated that among the key players in the palm oil industry, neither states nor nonstate actors have created sufficient initiatives for sustainable palm oil. Environmental and social considerations are still 
ranked lower than economic calculations. If this process continues, a more harmful environmental crisis will be inevitable, and food governance will be at risk. With palm oil making the most significant contribution to global vegetable oil supplies, a framework for a sustainable palm oil industry must go beyond environmental and social considerations and should consider world food security.

The current price mechanism is highly determined by demand and supply; therefore, if the CPOPC succeeds in raising the CPO price in the near future, companies should not take absolute advantage of this increase to fulfil demands and generate profit at the highest level. As a food commodity, palm oil should learn from other prominent food markets, such as the rice industry. Vietnam has offered very clear evidence that prioritising economic calculations as the highest interest can create other problems. As the world's second-largest rice exporter, Vietnam saw its rice industry benefit from high food prices in late 2008 by securing deals with many countries to such an extent that its production capacity was exceeded. When Vietnam failed to deliver as promised, the price of rice increased, and rice exports were later tightened (McMahon, 2013).

Moreover, as climate change continues to occur, the agriculture industry will face greater volatility than before. With palm oil production as their strategic industry, Malaysia and Indonesia are experiencing complex challenges. These two prominent Southeast Asian countries should not only target the key players in the palm oil industry to address these challenges but also share responsibilities to secure food governance via the implementation of sustainable palm oil production.

\section{Conclusion}

This paper has argued that Malaysia and Indonesia have strategic economic relations that emphasise the development of the palm oil industry. The features and relations of the two countries have also been discussed in the context of palm oil production. Both countries are involved in growing competition and collaboration. Developments such as the tax war, creation of ISPO and MSPO and establishment of MPOB and CSF are clear examples of the two countries' efforts to increase the competitiveness of their palm oil industries. Furthermore, the regionalisation of palm oil, which allows key actors in the two countries to benefit from technology transfers, capital inflows and labour mobility, is argued to be the outcome of stakeholder-driven collaborations. 
Furthermore, this paper has contended that Malaysia and Indonesia, along with other countries and stakeholders, need to manage the palm oil industry beyond profit calculations. Sustainability in palm oil production not only requires actions from these two countries but also creates problems for a market-driven scheme such as RSPO. The creation of CPOPC has been perceived as a positive collaboration between Malaysia and Indonesia. However, it is also expected to be a 'game changer' and a key player in the palm oil price mechanism.

More states need to be aware of palm oil as a major commodity to ensure that the industry would not create problems in terms of food governance. As main producers, Indonesia and Malaysia share common tasks and responsibilities to keep Southeast Asia's reputation as the worlds' biggest rice and palm oil exporters. According to Elkington's 'triple bottom line', sustainable palm oil and food governance are possible when environmental, social and economic bottom lines are considered equal policy priorities.

\section{References}

Amindoni, A. (2016). Govt. readies moratorium on palm oil, mining permits. The Jakarta Post. Retrieved May 21, 2016, from http://www.thejakartapost.com/news/2016/04/14/govt-readiesmoratorium-on-palm-oil-mining-permits.html

Artharini, I. (2016). Upaya memastikan bisnis kelapa sawit Indonesia ramah lingkungan. BBC Indonesia. Retrieved May 21, 2016, from http://www.bbc.com/indonesia/majalah/2016/02/160218_majalah_sertifik asi_kelapasawit

ASEAN Summit: KL, Jakarta form Council of Palm Oil Producing Countries. (2015, November 22). The Star. Retrieved May 21, 2016, from http://www.thestar.com.my/news/nation/2015/11/22/kl-jakarta-formcouncil-of-palm-oil-producing-countries/

Barakso, M., Sabet, D. M., \& Schaffner, B. (2013). Understanding Political Science Research Methods: The Challenge of Inference. New York: Routledge.

Bernhard, M. (2007). Making Measures Capture Concepts: Tools for Securing Correspondence between Theoretical Ideas and Observations. In T. Gschwend \& F. Schimmelfennig (Eds.), Research Design in Political Science (pp. 83-102). Hampshire: Palgrave Macmillan. 
Bowen, F. (2014). After Greenwashing: Symbolic Corporate Environmentalism and Society. London: Cambridge University Press.

Capistrano, A. D., \& Marten, G. G. (1986). Agriculture in Southeast Asia. In G. G. Marten (Ed.), Traditional Agriculture in Southeast Asia: A Human Ecology Perspective (pp. 6-8). Boulder: Westview.

Coordinating Ministry for Economic Affairs. (2011). Masterplan of Acceleration and Expansion of Indonesia Economic Development 2011-2025. Jakarta: Coordinating Ministry For Economic Affairs.

Cramb, R., \& McCarthy, J. F. (2016). Introduction. In R. Cramb, \& J. F. McCarthy (Ed.), The Oil Palm Complex: Smallholders, Agribusiness and the State in Indonesia and Malaysia (pp. 15-17). Singapore: National University of Singapore Press.

Creswell, J. W. (2009). Research Design: Qualitative, Quantitative, and Mixed Methods Approaches - Thousand Oaks: SAGE Publications.

Cronin, A. M. (2013). RSPO and 'Sustainable' Palm Oil: Is It All Greenwash? One Green Planet. Retrieved May 21, 2016, from http://www.onegreenplanet.org/news/rspo-and-sustainable-palm-oil-isit-all-greenwash/

Dollah, R., \& Mohamad, A. M. (2007). Malaysia-Indonesia Barter Trade: Opportunities and Challenges. JATI - Journal of Southeast Asian Studies, 12, 83-106.

Elkington, J. (1998). Cannibals with Forks: The Triple Bottom Line of 21st Century Business. Gabriola Island: New Island Publishers.

Experts in Sustainable Forest \& Agricultural Advice. (2015). Comparison of the ISPO, MSPO and RSPO Standards. Sustainable Palm Oil Transparency Toolkit. Retrieved May 21, 2016, from http://www.sustainablepalmoil.org/wpcontent/uploads/sites/2/2015/09/Efeca_PO-Standards-Comparison.pdf

FAO. (2016, May 5). Palm Oil Keeps Global Food Price Trend Heading Up in April. The Food and Agriculture Organization of the United Nations (FAO)'s website. Retrieved May 21, 2016, from http://www.fao.org/news/story/en/item/413122/icode/

Hall, D. (2011). Land Grabs, Land Control, and Southeast Asian Crop Booms. The Journal of Peasant Studies, 38(4), 837-857. Retrieved from https://doi.org/10.1080/03066150.2011.607706

Hapsari, M. (2016). Reworking Palm Oil Welfare from the Grassroots in Indonesia. E-International Relations. Retrieved June 30, 2016, from http://www.eir.info/2016/06/23/reworking-palm-oil-welfare-from-the-grassroots-inindonesia/ 
Indonesia dan Malaysia Kerjasama Industri Hilir Sawit. (2015, August 28). Tribun News. Retrieved May 21, 2016, from http://www.tribunnews.com/bisnis/2015/08/28/indonesia-dan-malaysiakerjasama-industri-hilir-sawit

Indonesia, Malaysia Team Up for Palm Oil Industrial Zone. (2015, October 5). The Jakarta Globe. Retrieved May 21, 2016, from http://jakartaglobe.beritasatu.com/business/indonesia-malaysia-teampalm-oil-industrial-zone/

Ivancic, H., \& Koh, L. P. (2016). Evolution of Sustainable Palm Oil Policy in Southeast Asia. Cogent Environmental Science, 2(1), 1-10. Retrieved from https://doi.org/10.1080/23311843.2016.1195032

Jacobson, P. (2016). Malaysian Palm Oil Companies Say their Concession Maps are State Secrets. Mongabay News. Retrieved May 21, 2016, from https://news.mongabay.com/2016/05/malaysian-palm-oil-companies-sayconcession-maps-state-secrets/

Jokowi Isyaratkan Tak Lanjutkan Program MP3EI dalam Pemerintahannya. (2014, September 5). Kompas. Retrieved May 21, 2016, from http://nasional.kompas.com/read/2014/09/05/17485041/Jokowi.Isyaratkan .Tak.Lanjutkan.Program.MP3EI.dalam.Pemerintahannya

King, G., Keohane, R. O., \& Verba, S. (1994). Designing Social Inquiry: Scientific Inference in Qualitative Research. Princeton: Princeton University Press. Retrieved from https://books.google.co.id/books?id=A7VFF-JR3b8C

Malaysian Palm Oil Board. (2015). About Us - Malaysian Palm Oil Board. Malaysian Palm Oil Board's website. Retrieved May 21, 2016, from http://www.mpob.gov.my/en/about-us/about

McMahon, P. (2013). Feeding Frenzy: The New Politics of Food. London: Profile Books.

Mhd. Nur M. S. (2018). Indonesia-Malaysia Relations from the Perspective of Maritime History of the Straits of Malacca. JATI - Journal of Southeast Asian Studies, 23(1), 64-74. Retrieved from https://jati.um.edu.my/index.php/jati/article/view/12187

Nesadurai, H. E. S. (2018a). New Constellations of Social Power: States and Transnational Private Governance of Palm Oil Sustainability in Southeast Asia. Journal of Contemporary Asia, 48(2), 204-229. Retrieved from https://doi.org/10.1080/00472336.2017.1390145

Nesadurai, H. E. S. (2018b). Transnational Private Governance as a Developmental Driver in Southeast Asia: The Case of Sustainable Palm Oil Standards in Indonesia and Malaysia. The Journal of Development 
Studies, $\quad 1-17 . \quad$ Retrieved $\quad$ from

https://doi.org/10.1080/00220388.2018.1536262

Nersesian, R. L. (2015). Energy for the 21st Century: A Comprehensive Guide to Conventional and Alternative Sources. London: M.E. Sharpe.

Primadhyta, S. (2015). Gapki Dukung Koalisi RI-Malaysia Jadi Penentu Bisnis CPO. CNN Indonesia. Retrieved May 21, 2016, from http://www.cnnindonesia.com/ekonomi/20151126161030-92-94306/gapkidukung-koalisi-ri-malaysia-jadi-penentu-bisnis-cpo/

Pye, O. (2009). Palm Oil as a Transnational Crisis in South-East Asia. Austrian Journal of Southeast Asian Studies, 2(2), 81-101.

Pye, O. (2016). Deconstructing the Roundtable on Sustainable Palm Oil. In R. Cramb, \& J. F. McCarthy (Eds.), The Oil Palm Complex: Smallholders, Agribusiness and the State in Indonesia and Malaysia (pp. 409-411). Singapore: National University of Singapore Press.

Raynolds, L. T., \& Bennett, E. A. (2015). Handbook of Research on Fair Trade. London: Edward Elgar Publishing.

Rownan, A. (2015). CPOPC Could Spell Trouble for Sustainable Palm Oil. Euro Monitor. Retrieved May 21, 2016, from http://blog.euromonitor.com/2015/11/cpopc-could-spell-trouble-forsustainable-palm-oil.html

RSPO. (2015). RSPO Membership. Roundtable on Sustainable Palm Pol. Retrieved May 21, 2016, from http://www.rspo.org/members/all

Sari, R. (2015). Rencana Kebijakan Crude Palm Oil Supporting Fund. Info Singkat Ekonomi dan Kebijakan Publik, VII(07), p. 15.

Sime Darby Plantation. (2014). Palm Oil Facts \& Figures. Sime Darby's website. Retrieved May 21, 2016, from http://www.simedarby.com/upload/Palm_Oil_Facts_and_Figures.pdf

Simoes, A., \& Hidalgo, C. (2014). Country Profile: Malaysia \& Indonesia. The Economic Complexity Observatory: An Analytical Tool for Understanding the Dynamics of Economic Development. Retrieved May 21, 2016, from http://atlas.media.mit.edu/en/

Taylor, M. (2014). Indonesia Likely to Keep Palm Export Tax at Zero For Nov Industry. Reuters Asia. Retrieved May 21, 2016, from http://www.reuters.com/article/indonesia-palmoil-taxidUSL3N0S93KV20141014

Thanh, N. C., \& Thanh, T. T. Le. (2015). The Interconnection Between Interpretivist Paradigm and Qualitative Methods in Education. American Journal of Educational Science, 1(1), 24-27. 
Tian, G., \& Lassa, J. A. (2015, January 17). Get Ready for Future Crisis in Food Production in Southeast Asia. The Jakarta Post. Retrieved May 21, 2016, from http://www.thejakartapost.com/news/2015/01/17/get-ready-futurecrisis-food-production-southeast-asia.html

Tuah, Y. (2016). Indonesia's CPO Export Tax Hike Good News for Malaysia. Borneo Post Online. Retrieved May 21, 2016, from http://www.theborneopost.com/2016/04/29/indonesias-cpo-export-taxhike-good-news-for-malaysia/\#ixzz47Cy8AXmn

United States Department of Agriculture. (2010). Indonesia: Rising Global Demand Fuels Palm Oil Expansion. Commodity Intelligence Report. Retrieved May 21, 2016, from http://www.pecad.fas.usda.gov/highlights/2010/10/indonesia/

Varkkey, H. (2012). Patronage Politics as a Driver of Economic Regionalisation: The Indonesian Oil Palm Sector and Transboundary Haze. Asia Pacific Viewpoint, 53(3), 314-329.

Vidal, J. (2013). Major Palm Oil Companies Accused of Breaking Ethical Promises. The Guardian. Retrieved May 21, 2016, from https://www.theguardian.com/environment/2013/nov/06/palm-oilcompanies-ethical-report

Wardhani, B. L. S. W. (2009). Trend in Indonesia -Malaysia Bilateral Relations in Post-Suharto Period. Indonesian Journal of Social Sciences, 1(1), 1-9.

Willis, J. W., Jost, M., \& Nilakanta, R. (2007). Foundations of Qualitative Research: Interpretive and Critical Approaches. Thousand Oaks: SAGE Publications.

Wong, J. (2016). Call to End Palm Oil Price War. The Star. Retrieved May 21, 2016, from http://www.thestar.com.my/business/businessnews/2016/02/06/call-to-end-palm-oil-price-war/ 